\title{
Alternatywny scenariusz biografii muzyka rockowego - o życiu i twórczości Jasona Beckera
}

KEY WORDS

rock culture, musician biographies, documentary film, narratives

\begin{abstract}
Kosek Jakub, Alternatywny scenariusz biografii muzyka rockowego o życiu i twórczości Jasona Beckera [An Alternative Script of the Biography of a Rock Musician - About the Life and Work of Jason Becker]. Kultura - Społeczeństwo - Edukacja nr 2(10) 2016, Poznań 2016, pp. 191-200, Adam Mickiewicz University Press. ISSN 2300-0422. DOI 10.14746/kse.2016.10.15.

The article focuses on the analysis of the biography of an American rock guitarist, namely Jason Becker. The main object of this study was the documentary "Jason Becker. Not Dead Yet" (2012) and some selected press news and information available on social media. The original biography of the musician, who within a few years has become famous in the world of rock music and since the age of 19 has had to confront the incurable disease - amyotrophic lateral sclerosis - is an interesting example of the alternative model of a biography in popular culture. It is also an educational story that teaches fundamental values, such as altruism, love, respect and friendship.
\end{abstract}

Interesującą płaszczyzną dla rozważań nad kulturą jako przestrzenią uczenia się jest rock, który, jak zauważa Marcin Rychlewski, stanowi obok filmu, telewizji, komputera oraz Internetu jedno $\mathrm{z}$ najistotniejszych zjawisk kulturotwórczych drugiej połowy XX wieku (Rychlewski, 2011: 7). Wśród historii życia rozmaitych twórców kultury rockowej odnaleźć można wiele interesujących i wyjątkowych biografii. 


\section{Biografie twórców rockowych}

Powszechnie $\mathrm{w}$ dziejach muzyki popularnej znane i chętnie komentowane są życiorysy szczególnie kilku artystów, którzy zmarli w młodym wieku, dokładnie w dwudziestym siódmym roku swojego życia. W kulturze popularnej wykrystalizował się termin, mający w specyficzny sposób objąć sylwetki zmarłych w tym wieku muzyków, mianowicie pojęcie tak zwanego „Klubu 27”. Jako najsłynniejsze postaci wchodzące w „skład” owego klubu, przede wszystkim wskazywani są: słynny gitarzysta Jimi Hendrix (1942-1970), instrumentalista i założyciel zespołu The Rolling Stones - Brian Jones (1942-1969), amerykańska wokalistka Janis Joplin (1943-1970), lider grupy The Doors - Jim Morrison (1943-1971), wokalista formacji Nirvana - Kurt Cobain (1967-1994) oraz piosenkarka Amy Winehouse (1983-2011).

Sama idea „Klubu 27”, co szczególnie interesujące - stanowiła również przedmiot badań naukowych. Martin Wolkewitz, Arthur Allignol, Nicholas Graves oraz Adrian Barnett - autorzy artykułu opublikowanego w czasopiśmie „British Medical Journal”, wykorzystując metodę statystyczną, dokonali analizy 1046. artystów (solistów oraz grup muzycznych), którzy w latach 1956-2007 wydali co najmniej jedną płytę notowaną na pierwszym miejscu na brytyjskiej liście przebojów - nagła śmierć spotkała 71 twórców, co stanowi 7\% z całkowitej liczby badanych. Naukowcy dostrzegli, iż mit „Klubu 27” zakładał, że muzycy są bardziej narażeni na śmierć w dwudziestym siódmym roku życia, tymczasem przeprowadzone przez nich badania wykazały, iż dwudziestoletni oraz trzydziestoletni muzycy mają na ogół zwiększone ryzyko śmierci, zaś sama sława, z którą muszą poradzić sobie artyści - może zwiększać owo ryzyko, aczkolwiek nie należy ograniczać go do 27. roku życia (Wolkewitz, A. Allignol, N. Graves, A. Barnett, 2011).

Oczywiście, mit „Klubu 27” jest zjawiskiem nośnym pod względem medialnym. Wyżej wymienieni muzycy to postacie wyraziste i utalentowane, które odniosły sukces dzięki swej pracowitości i kreatywności. Artyści tacy jak Jimi Hendrix czy Janis Joplin stworzyli albumy, dzięki którym odnieśli zarówno sukcesy artystyczne, jak i komercyjne - dziś natomiast ich dokonania stanowią kanon rocka. Nagła śmierć wspomnianych twórców stanowiła niezwykle przykre wydarzenie dla ich miłośników, ale zarazem utrwaliła, formułującą się już za życia muzyków - swoistą mitologię artystyczną.

Kontrapunkt dla biografii zmarłych w młodym wieku twórców rockowych mogą stanowić choćby życiorysy artystów urodzonych w latach czterdziestych ubiegłego wieku, będących wciąż jednostkami aktywnymi w sferze artystycznej. Wśród wielu znamienitych i zasłużonych dla kultury rocka osobistości wymienić należy Paula McCartneya, Erica Claptona, Davida Gilmoura, Patti Smith czy Iana 
Gillana. Warto wspomnieć również o protoplastach rocka, którym do dziś zdarza się jeszcze występować publicznie. Do owych aktywnych klasyków zaliczają się między innymi: Jerry Lee Lewis, Chuck Berry czy John Mayall - artyści, którzy przekroczyli już osiemdziesiąty rok życia. Na tle rozmaitych biografii twórców kultury rocka wyjątkowe miejsce zajmuje historia życia amerykańskiego gitarzysty Jasona Beckera. Reżyser Jesse Vile postanowił w formie filmu dokumentalnego przedstawić szerokiej publiczności niecodzienne koleje losu muzyka.

Danuta Lalak konstatuje, iż biografia, najogólniej rzecz ujmując, to: „historia życia, droga życiowa od narodzin aż do śmierci - to pełny cykl ludzkiego życia”, zaś samo „słowo «biografia» oznacza opis życia, czyli tekst (gr. bios - życie i grapho - piszę)", a także dostrzega, że równocześnie określa się tym słowem to, co jest przedmiotem opisu, czyli życie ludzkie w jego rzeczywistym wymiarze" (Lalak, 2010: 105) ${ }^{1}$. Biografia amerykańskiego gitarzysty to niecodzienna historia utalentowanego instrumentalisty, który w kulminacyjnym momencie swojej kariery muzycznej musiał skonfrontować się $\mathrm{z}$ dramatycznym wydarzeniem - nieuleczalną i postępującą chorobą, zdiagnozowaną jako stwardnienie zanikowe boczne.

Film dokumentalny, zatytułowany Jason Becker. Ciagle żywy rozpoczyna się od ujęcia, w którym młody muzyk wraz ze swym wujem Ronem Beckerem radośnie wykonują fragment utworu $\mathrm{z}$ repertuaru Boba Dylana, pt. Mr. Tambourine Man. Następnie, jeszcze przed pojawieniem się tytułu filmu, zaprezentowane zostają rozmaite urywki z ekspresyjnych występów gitarzysty, a także zbliżenia na okładki muzycznych czasopism, na których widniała sylwetka muzyka. „To niepojęte, że on jeszcze żyje. Ale żyje” - padają słowa matki Pat Becker i równocześnie odbiorca dostrzega na ekranie kadr przedstawiający dojrzałego - ponadczterdziestoletniego - unieruchomionego muzyka. Przez kolejną godzinę produkcji poznajemy historię młodego twórcy opowiedzianą przez bliskie mu osoby - członków rodziny oraz artystów.

Jason Eli Becker urodził się 22 lipca 1969 roku w Richmond w amerykańskim stanie Kalifornia, miesiąc przed wyznaczonym terminem narodzin. Rodzice przyszłego muzyka, będący znaczącymi bohaterami produkcji, wspominają, iż jako dziecko nie chciał on chodzić do szkoły i potrafił zupełnie nie odzywać się do nauczycieli, po wizycie u psychologa zaczął jednak prędko funkcjonować jak zwyczajny, początkowo niewyróżniający się spośród innych uczeń. Jednym z przełomowych wydarzeń w życiu Beckera było otrzymanie z okazji świąt Bożego Narodzenia pierwszej niecierpliwie wyczekiwanej gitary. Wuj nauczył chłopca podstawowych akordów, zaś ojciec szkolił syna $\mathrm{z}$ zasad zapisu nutowego.

${ }^{1}$ Autorka podkreśla jednak wieloznaczność oraz rozmaite konteksty pojęcia „biografia”, zob. s. $106-114$. 
W szóstej klasie, podczas pokazu talentów, młody muzyk wykonywał już na harmonijce ustnej i gitarze utwory z repertuaru Boba Dylana.

Gitarzysta wciąż udoskonalał swoje umiejętności, słuchał albumów Erica Claptona i potrafił „ze słuchu” odtworzyć partie gitary. We wspomnianym dokumencie zaprezentowany jest, między innymi fragment, w którym piętnastoletni muzyk wychodzi na scenę i daje popis swoich imponujących umiejętności. Matka młodego wirtuoza Pat Becker wspomina, iż Jason, aby uzyskać satysfakcjonujące go rezultaty, grał na gitarze niemal bez przerwy, zarówno w trakcie kolacji, jak i w czasie podróży samochodem na specjalnym, kupionym na tę okoliczność mniejszym instrumencie. Mógł on jednak liczyć na zrozumienie, wsparcie i pomoc w rozwijaniu pasji muzycznej ze strony rodziców. Pat Becker wspomina okres rozwojowy swojego dziecka następująco:

Jason, mając koło 10-11 lat, przyszedł do mnie i powiedział, że musi podjąć decyzję, na czym w życiu powinien się skupić: football czy granie na gitarze. I zdecydował, że to właśnie muzyka będzie jego przyszłością. Dość wczesna deklaracja, jak na chłopca w jego wieku,

w innym zaś miejscu dodaje:

Jason robił nieprawdopodobne postępy. Z czasem musiał, jak każdy artysta, zmieniać sprzęt na nowszy, lepszy. Robiliśmy wszystko, by dotrzymać tempa jego muzycznemu rozwojowi, ale nigdy nie mieliśmy poczucia, że Jason nie zasługuje na nową gitarę, wzmacniacz czy klawisze. Przychodził i prosił, by mu coś kupić, a my staraliśmy się wywiązywać z danego mu słowa. (Kubicki, 2013)

Jason Becker poświęcił się muzyce, ograniczył kontakty towarzyskie, a także - aby móc zająć się nagraniem płyty i wyruszyć w trasę koncertową - ukończył pół roku wcześniej szkołę, uzyskując bardzo dobre wyniki. Ważną postacią w życiu muzyka okazał się artysta Marty Friedman, którego poznał, gdy miał 16 lat. Sformował wraz z nim oraz kilkoma innymi twórcami zespół, który można definiować, wykorzystując terminologię Ervinga Goffmana, jako każdą grupę osób „współpracujących ze sobą w inscenizacji jakiegokolwiek fragmentu przedstawienia" (Goffman, 1981: 109). Jako nazwę grupy wybrali dość autoironicznie w kontekście prezentowanego materiału - Cacophony. Pod tym szyldem wydali dwie płyty: Speed Metal Symphony (z 1987), w której tytule zawarta została swoista deklaracja gatunkowa, oraz Go Off! (1988).

Młody Becker w doskonały sposób zarządzał „fasadą osobistą", a więc tymi środkami wyrazu, które są "najmocniej związane z samym wykonawcą i przemieszczają się razem z nim" - jej elementami według koncepcji amerykańskiego socjologa mogą być „insygnia związane z pozycją i urzędem, strój, płeć, wiek, cechy rasowe, postura i wygląd, sposób mówienia, mimika, gesty itd." (Goffman, 
1981: 54). Amalgamat wysokiej, szczupłej sylwetki muzyka z długimi, ciemnymi, bujnymi włosami, ubranego w dżinsowe lub skórzane spodnie, kamizelki i czarne rękawiczki, tworzył wręcz perfekcyjny image rockowego idola. Becker znakomicie zachowywał się na scenie, potrafił wykreować niezwykle kunsztowny pod względem instrumentalnym i wizerunkowym sceniczny rytuał.

\section{Choroba jako przełomowy punkt w biografii muzyka}

Angielski socjolog i badacz rocka Simon Frith dostrzega, iż głos wokalisty należy ujmować z czterech punktów widzenia: jako instrument muzyczny, jako ciało, jako osobę, a także jako postać (Frith, 2011: 254). W kontekście twórczości Jasona Beckera warto zatrzymać się przy pierwszej z wymienionych wyżej kategorii. Gitarzysta na szerszą skalę nigdy nie udzielał się wokalnie, jednak w przypadku jego oryginalnej techniki i stylu gry można by stwierdzić, iż to właśnie instrument muzyczny pełnił funkcję artystycznego "głosu” utalentowanego instrumentalisty. Na fakt, iż „głos” muzyka nie musi wyłącznie ograniczać się do głosu w sensie fizycznym, zwracał uwagę także S. Frith, omawiając przykład jazzmanów, którzy jak stwierdza „ "przemawiają» swoimi instrumentami” (Frith, 2011: 259). Zgodzić się jednak należy z obserwacją angielskiego badacza, iż „ekspresję za pomocą głosu uznaje się za bardziej bezpośrednią od ekspresji za pomocą gitary czy perkusji, za więcej mówiącą" (Frith, 2011: 260). Brzmienie gitary Beckera - ze zmagazynowaną w nim pasją, jego umiejętności techniczne i kompozycyjne oraz instrumentalne wyczucie - stanowiące, nieprzeciętny, estetyczny, dźwiękowy komunikat nazwać można by w metaforyczny sposób - „mową” tego artysty. W jego biografii "głosem” zaś, z którym mógł stworzyć fenomenalny duet, miał okazać się słynny amerykański wokalista i kompozytor David Lee Roth. Becker zdążył wcześniej nagrać swój solowy album, zatytułowany Perpetual Burn (1988), którego zawartość przekonała decyzyjne osoby o włączeniu młodego muzyka do składu zespołu popularnego rockmana.

W początkowym okresie współpracy gitarzysty z zespołem Lee Rotha młody artysta zaczął jednak odczuwać pierwsze objawy choroby - drętwienie nóg, rąk i dłoni. Schorzenie zostało zdiagnozowane jako stwardnienie zanikowe boczne, znane także jako choroba Lou Gehriga lub ALS (skrót od ang. Amyotrophic Lateral Sclerosis). Postępujący paraliż uniemożliwił muzykowi wyruszenie $\mathrm{w}$ trasę koncertową. To dramatyczne wydarzenie stanowiło przełomowy punkt $\mathrm{w}$ jego biografii. W wielu rozmaitych przypadkach, jak zauważa Danuta Lalak, odnosząc się do badań poczynionych przez niemiecką uczoną Charlotte Bühler, „załamanie się opartego na witalności stylu życia nie następuje dobrowolnie ani stopniowo i w ten sposób przewidywalnie, lecz pod przymusem utraty zdrowia, w wyni- 
ku nagłego wydarzenia losowego, wypadku czy innych okoliczności” (Lalak, 2010: 146), owe wydarzenia powodują gruntowną zmianę w życiu (Lalak, 2010: 146). Bühler w pracy Bieg życia ludzkiego analizowała, między innymi, postaci Josepha Conrada oraz Alfreda Tetensa, które musiały stosunkowo wcześnie zrezygnować ze swojej życiowej pasji, jaką było żeglowanie - pierwszy z wymienionych mężczyzn na skutek uciążliwie powracającej gorączki w wieku 36 lat, drugi natomiast do przerwania kariery marynarskiej został zmuszony z powodu złamania kości udowej (Bühler, 1999). Mający ponad dwadzieścia lat Jason Becker, będąc zatem w znacznie młodszym wieku od wspomnianych wyżej postaci, musiał skonfrontować się ze szczególnie dramatycznym wydarzeniem w swoim życiu.

Irena Hausmanowa-Petrusewicz oraz Janina Rafałowska opisują chorobę Lou Gehriga następująco:

Jest to postępujące wybiórcze uszkodzenie neuronów ruchowych - obwodowego i ośrodkowego (...) Objawy często zaczynają się asymetrycznie. Początek jest podstępny, dopiero utrata około 50\% jednostek ruchowych znajduje odbicie w obrazie klinicznym. Początek choroby przypada najczęściej pomiędzy 40. a 60. rż., ok. 5\% przypadków może zaczynać się przed 30. rż. (...) Dwukrotnie częściej chorują mężczyźni (M:F - 2:1). Zazwyczaj przebieg jest ciężki, śmierć następuje po 1,5-4 latach od pierwszych objawów klinicznych, $20 \%$ przypadków ma przebieg dłuższy niż 5 lat, bywają jednak postacie bardziej przewlekłe o przebiegu nawet 10-letnim. (Hausmanowa-Petrusewicz, Rafałowska, 2004: 434-441)

Jason Becker 22 lipca 2015 roku skończył 46 lat, mimo iż po zdiagnozowaniu choroby gitarzyście prognozowano zaledwie kilka lat życia.

Amerykański muzyk, pomimo swojego stanu, nie zaprzestał tworzenia muzyki i postanowił nagrać studyjną płytę. Wciąż mógł komponować, zachował talent, posiadał wyczucie tempa, harmonii i frazy. Dzięki pomocy przyjaciela i nowoczesnej wówczas technologii stworzył album Perspective. W filmie dokumentalnym Jason Becker. Ciagle żywy bliscy muzyka nie ukrywają podziwu dla twórcy, zostaje on nawet nazwany „pracoholikiem”2. Ojciec artysty Gary Becker, aby ułatwić synowi komunikację z otoczeniem, opracował system, za pośrednictwem którego chory muzyk porozumiewa się za pomocą znaków przekazywanych oczami. Rodzic nazywa to "geometrią wzrokową" - każdej literze alfabetu odpowiada spojrzenie pod odpowiednim kątem. W dokumencie widz może zapoznać się z zaprezentowaną metodą. Muzyk przed kamerą odznacza się poczuciem humoru, za pomocą znaków dawanych oczyma komunikuje do widzów następującą treść: „Proszę Państwa. To Jason Becker. Najseksowniejszy facet na

${ }^{2}$ Dokument filmowy: Jason Becker. Ciagle żywy, reż. Jesse Vile, USA/UK, 2012. 
świecie”, później kilkakrotnie udowadnia, iż mimo swojego stanu potrafi żartować - na przykład w scenie, w której zwraca uwagę ojcu, że każde jego słowo jest ważne, bo nie używa on słów - „wypełniaczy”.

Ważną postacią w biografii Beckera jest Serana - kobieta, która wcześniej była partnerką muzyka, pozostała jednak jego przyjaciółką i opiekunką, przygotowuje mu odpowiednie posiłki i dba o jego zdrowie. Bohaterowie dokumentu zauważają, że opieka nad muzykiem to dobrze zorganizowana praca zbiorowa członków rodziny i przyjaciół, którzy zajmują się nim z dużym poświęceniem.

W filmie dokumentalnym przedstawione zostały również relacje, jakie łączą muzyka z fanami. Na cześć gitarzysty organizowane są festiwale (seria Jason Becker's Not Dead Yet Festival), w których poza miłośnikami twórczości gitarzysty, uczestniczą też inni, popularni w kulturze rocka artyści, tacy jak Marty Friedman, Joe Satriani czy Richie Kotzen. Dokument kończy się sekwencją ze spotkania muzyka $\mathrm{z}$ fanami, a także krótką sceną będącą fragmentem nagrania z początku produkcji - w której młody Jason Becker grał wraz z wujem utwór Boba Dylana zatytułowany Mr. Tambourine Man. To symboliczna kompozycja w kontekście historii życia muzyka. Amerykański bard był jednym z pierwszych autorytetów muzycznych gitarzysty. Ponadto w tekście piosenki, w drugiej zwrotce padają następujące słowa: „Take me on a trip upon your magic swirlin' ship/ My senses have been stripped, my hands can't feel to grip/ My toes too numb to step, wait only for my boot heels/ To be wanderin" "3. Treść utworu Dylana była niejednokrotnie rozmaicie interpretowana przez fanów i krytyków, jednak w kontekście życia i twórczości Beckera wersy te brzmią szczególnie symbolicznie.

\section{Biografia Jasona Beckera w kontekstach kulturowych}

Omawiana w niniejszym szkicu historia życia ludzkiego to wartościowa poznawczo narracja nieprzeciętnego twórcy rockowego. Oryginalny życiorys artysty stanowi interesujący przykład alternatywnego modelu biografii twórcy kultury popularnej. Jest to także edukacyjna historia, która uczy o fundamentalnych wartościach - altruizmie, miłości, szacunku i przyjaźni. Postać Jasona Beckera nie ma wiele wspólnych cech $\mathrm{z}$ obliczem stereotypowego rockmana. Obce $\mathrm{w}$ przypadku jego życia jest hasło „sex, drugs and rock'n'roll”, któremu hołdowały szcze-

\footnotetext{
${ }^{3}$ Zabierz mnie w podróż magicznym statkiem twym/ Moje zmysły zostały obnażone, moje ręce nie czują chwytu/ Palce moich nóg są zbyt zdrętwiałe by stąpać, czekają tylko/ aż me obcasy zaczną wędrować., tłumaczenie tekstu utworu dostępne w serwisie internetowym: www.tekstowo.pl. Dokument elektroniczny dostępny na stronie: http://www.tekstowo.pl/piosenka,bob_dylan,mr_tambourine_man.html, dostęp: 20.08.2015.
} 
gólnie niektóre grupy muzyczne, jak choćby Mötley Crüe czy Guns N’Roses. Muzykowi natomiast zależało na ukończeniu szkoły, a w trakcie tras koncertowych, zamiast oddawać się beztroskiej zabawie, wolał ćwiczyć swój warsztat i prowadzić rozmowy telefoniczne $\mathrm{z}$ rodziną i bliskimi. $\mathrm{W}$ trakcie choroby nie poddał się, postanowił $\mathrm{w}$ miarę możliwości tworzyć i utrzymywać kontakty z fanami. Jeżeli odniosłoby się dotychczasową historię życia gitarzysty do elementów narracji mitycznej, wypunktowanych przez Marka Jezińskiego (zob. Jeziński, 2014: 149-150) - pełniących znaczącą funkcję w kreowaniu mitologii artystycznej twórców muzyki popularnej - można by zauważyć, iż komponenty te częściowo tylko występowały w biografii Beckera. Miał on dobre kontakty $\mathrm{z}$ rodzicami; „poszukiwanie własnego miejsca” w jego przypadku było zogniskowane na muzyce - będąc dzieckiem podjął już decyzję o zostaniu muzykiem (etap „Podjęcie wyprawy”) i plan ten konsekwentnie realizował; występował solo oraz z zespołami (element - „Droga”), nie naruszał on zakazów, a przeciwności losu umiejętnie pokonywał. Kluczowym elementem narracji w historii muzyka jest komponent nazywany „walką z potworami” - w jego przypadku jest to choroba Lou Gehriga, z którą do dziś się konfrontuje.

Jason Becker jest jednak ciągle aktywny jako użytkownik sieci internetowej. Posiada oficjalną stronę ${ }^{4}$ w której odnaleźć można między innymi aktualne informacje, fotografie oraz nagrania wideo $\mathrm{z}$ różnych etapów jego kariery. Film dokumentalny, w którym przedstawiona została historia amerykańskiego gitarzysty, to tylko jedna $\mathrm{z}$ platform medialnych, tworzących specyficzną transmedialną narrację $e^{5}$ tego twórcy. Interesujące jest funkcjonowanie owej jednostki w kulturze konwergencji, w której jak zauważa Henry Jenkins „przecinają się drogi starych i nowych mediów, gdzie zderzają się media fanowskie i korporacyjne, gdzie władza producenta mediów i władza konsumenta mediów wchodzą $\mathrm{w}$ nieprzewidywalne interakcje" (Jenkins 2007: 8). Becker jest czynnym użytkownikiem serwisów społecznościowych, na profilu muzyka w serwisie Twitter oraz Facebook ${ }^{6}$ można odnaleźć, między innymi wiele wpisów koncentrujących się wokół jego dawnych występów, jak również współczesne fotografie z rozmaitymi artystami, przyjaciółmi i członkami rodziny.

Gitarzysta ma liczne grono fanów mieszkających w wielu zakątkach świata. Są to aktywne i kreatywne osoby, które zainspirowane dokonaniami Amerykanina chętnie komponują swoje autorskie piosenki, a także nagrywają covery jego

\footnotetext{
${ }^{4}$ Zob. http://jasonbeckerguitar.com/, dostęp: 10.09.2015.

${ }^{5}$ Kategoria tzw. opowiadania transmedialnego została szczegółowo opisana przez amerykańskiego medioznawcę Henry'ego Jenkinsa, zob. Jenkins 2007.

${ }^{6}$ Stan w dniu 15.09.2015: w serwisie Twitter oficjalne konto Jasona Beckera obserwują 9463 osoby, zob. https://twitter.com/jasonelibecker, zaś liczba fanów gitarzysty w portalu Facebook wynosi 247 948, zob. https://www.facebook.com/jasonelibecker/timeline, dostęp: 15.09.2015.
} 
utworów. W sieci internetowej odnaleźć można wiele krótkich filmów wideo (tzw. tribute videos), stanowiących hołd dla dokonań instrumentalisty ${ }^{7}$. Miłośnicy twórczości gitarzysty tworzą również rysunki, amatorskie obrazy oraz inne teksty kultury będące wyrazem ich sympatii dla Amerykanina. Niejednokrotnie stworzone przez nich prace są udostępnianie w sieci internetowej i przesyłane pomiędzy tysiącami użytkowników udzielających się między innymi na forach i portalach społecznościowych w różnych częściach świata. Becker za pośrednictwem serwisów internetowych komunikuje się z fanami, często chwali i promuje początkujących twórców, a także komentuje wybrane wydarzenia muzyczne. Powstają również profesjonalne wydawnictwa, stanowiące hołd dla muzyka złożony mu przez innych artystów, warto tu wspomnieć takie produkcje, jak Warmth in the Wilderness: A Tribute to Jason Becker (2001) czy Warmth in the Wilderness, Vol. 2: A Tribute to Jason Becker (2002). Wyżej wymienione zachowania jednostek - między innymi fanów, muzyków i producentów wpisują się w koncepcję kultury uczestnictwa (Jenkins, 2007: 9), czyli kultury w rozumieniu Jenkinsa, w której „fani i inni konsumenci są zapraszani do aktywnego uczestnictwa w tworzeniu i redystrybucji nowych treści” (Jenkins, 2007: 257).

Podsumowując powyższe rozważania, warto podkreślić kilka kwestii. Na tle rozmaitych biografii twórców rockowych historia Jasona Beckera zajmuje miejsce szczególne. Ta niesztampowa i oryginalna, choć w istocie dramatyczna opowieść utalentowanego gitarzysty, stanowi przykład życia i twórczości heavymetalowego muzyka, kontrastującego z potocznym i stereotypowym wyobrażeniem „gwiazdy rocka”, zwłaszcza reprezentanta sceny hard/heavy. Artysta swoimi unikalnymi instrumentalnymi wykonaniami i kompozycjami, zarejestrowanymi na wydanych dotychczas albumach, „przemawia” do odbiorców. Oczywiście, znajomość kontekstu biograficznego $\mathrm{w}$ przypadku odbioru płyt współtworzonych przez muzyka, z dzisiejszej perspektywy pozostaje nie bez znaczenia. Choroba stanowiła w życiu Beckera punkt przełomowy. Pomimo tragicznej sytuacji, w której się znalazł, nie poddał się, podjął walkę z przeciwnościami losu - szczególne zatem znaczenie odgrywa w biografii artysty element narracji mitycznej istotny w kreowaniu mitologii artystycznej, określany jako „walka z potworami” (Jeziński, 2014: 149-150).

Życie Beckera bezpośrednio łączy się również z nowymi technologiami informacyjno-komunikacyjnymi. Nie tylko pozwalają mu one na codzienną egzystencję (specjalistyczna aparatura), ale także sam gitarzysta wykorzystuje je do prób dalszego tworzenia (za pomocą programów komputerowych) oraz komunikowania się z odbiorcami i fanami swojej twórczości (nowe media, social media).

\footnotetext{
${ }^{7}$ Zob. nagrania dostępne w sieci internetowej: https://www.youtube.com/watch?v=4fUIJvCYpAY, https://www.facebook.com/jasonelibecker/posts/1190356744312471, dostęp: 26.10.2015.
} 
$\mathrm{Na}$ interesującą biografię muzyka warto więc spoglądać przez pryzmat takich zjawisk jak kultura partycypacji oraz konwergencja mediów. Zaprezentowana w tym miejscu w syntetycznym ujęciu historia amerykańskiego gitarzysty to wyjątkowa biografia artysty, który inspiruje kolejne pokolenia twórców. Unikatowy życiorys Jasona Beckera na stałe zapisze się nie tylko w historii rocka, ale, ze względu na swój edukacyjny potencjał, także w dziejach szeroko rozumianej kultury popularnej.

\section{Literatura}

Bühler Ch. (1999). Bieg życia ludzkiego. Warszawa 1999.

Frith S. (2011). Sceniczne rytuały. O wartości muzyki popularnej. Kraków.

Goffman E. (1981). Człowiek w teatrze życia codziennego. Warszawa.

Hausmanowa-Petrusewicz I., Rafałowska J. (2004). Stwardnienie zanikowe boczne. [W:] W. Kozubski, P. Liberski. Choroby układu nerwowego. Warszawa.

Jenkins H. (2007). Kultura konwergencji. Zderzenie starych i nowych mediów. Warszawa.

Jeziński M. (2014). Mitologie muzyki popularnej. Toruń.

Kubicki M. (2013). Jason Becker. Studium geniuszu, http://www.magazyngitarzysta.pl/ludzie/artykuly/ 12734-jason-becker-studium-geniuszu.html, dostęp: 16.08.2015.

Lalak D. (2010). Życie jako biografia. Podejście biograficzne w perspektywie pedagogicznej. Warszawa. Rychlewski M. (2011). Rewolucja rocka. Semiotyczne wymiary elektrycznej ekstazy. Gdańsk.

Siwak W. (1999). Estetyka rocka. Warszawa.

Wolkewitz M., Allignol A., Graves N., Barnett A. (2011). Is 27 really a dangerous age for famous musicians? Retrospective cohort study, http://www.bmj.com/content/343/bmj.d7799, dostęp: 10.08.2015.

\section{Filmografia}

Jason Becker. Ciagle żywy, reż. Jesse Vile, USA/UK, 2012

Serwisy internetowe:

www.facebook.com, https://www.facebook.com/jasonelibecker/timeline, dostęp: 15.09.2015.

www. jasonbeckerguitar.com, http://jasonbeckerguitar.com/, dostęp: 10.09.2015.

www.tekstowo.pl, http://www.tekstowo.pl/piosenka,bob_dylan,mr_tambourine_man.html, dostęp: 20.08.2015.

www.twitter.com, https://twitter.com/jasonelibecker, dostęp: 15.09.2015. 